\title{
Numerical analysis of Composite with Natural Fiber Reinforcement using Finite Element Method: Leaf Spring Composite Application
}

\author{
Amirin Kusmiran ${ }^{1}$, Muhamad Hidayat ${ }^{2}$, Rita Desiasni ${ }^{3}$, Ahmad Zadi Maad ${ }^{4}$ \\ ${ }^{1,3,4}$ Departement of Metallurgy Engineering, Faculty of Engineering, Universitas Teknologi \\ Sumbawa, Indonesia. 84354 \\ ${ }^{2}$ Departement of Mechanical Engineering, Faculty of Engineering, Universitas Teknologi \\ Sumbawa, Indonesia. 84354 \\ \{amirin19@gmail.com¹,muhamad.hidayat@uts.ac.id², rita.desiasni@uts.ac.id ${ }^{3}$, \\ ahmad.zadi.maad@uts.ac.id $\left.{ }^{4}\right\}$
}

\begin{abstract}
Leaf spring is one of component that use to vibration damping on vehicle, where one of material that use to fabrication this component is $55 \mathrm{Si} 7$ steel. Currently, sustainable product is main focus in industry, so that composite is a potential alternative to replace steel as leaf spring. Materials that use to composite fabrication are sisal as fiber, epoxy as matrix, and honeycomb and alumunium alloy as core, where fabrication both $55 \mathrm{Si} 7$ steel and composite specimen are based on ASTM D638 standard. Fabrication of composite specimen conducted by hand lay-up technique, and mechanical properties analysis of thus specimen are conducted by finite element method. Tensile test is tested on $55 \mathrm{Si} 7$ steel and composite specimen using finite element method. According tensile test, steel of 55Si7 type have $2.92 \mathrm{~mm}$ of total deformation average, and $12583 \mathrm{MPa}$ of strain, composite natural fiber with honeycomb core have $62.75 \mathrm{~mm}$ of total deformasi average, and $18590 \mathrm{MPa}$ of stress, and composite natural fiber with aluminium alloy core have $15.47 \mathrm{~mm}$ of total deformasi average, and $12813 \mathrm{MPa}$ of stress. According that results, composite with aluminium alloy core have the mechanical properties close to $55 \mathrm{Si} 7 \mathrm{steel}$ than composite honeycomb core.
\end{abstract}

Keywords: Sisal Fiber, Finite Element Method, Hand Lay-up Technique, Leaf Spring.

\section{Introduction}

Steel leaf spring is one of the component used in the automotive industry which use to reduce vibration. One of the problem caused by steel leaf spring is corrosive, so that it can cause steel leaf spring to degrade mechanical strength. alternatively, the development of suistanable and durable composite leaf spring with the natural fiber is needed, so that it become an economically valuable product. In generally, the development natural fiber as reinforcement in composite fabrication [7], and composite leaf spring fabrication have been succesfully with use the fiber glass which is conducted by $[12,15]$. Analysis of mechanical properties of composite leaf spring has been conducted by Singh, H., et al, 2018 [11]. Composite have adventage such as not corrosion, light weight, and mechanical properties can be designed easily. The main porpose of mechanical design is to get the optimum compositions of the composite material, so that time 
and cost can be efficient to material fabrications [5,6]. Optimum condition can be determined through the design and simulation of composite laminates. Finite element method has been succesfully bio-composite analysis with natural fiber to determine optimal of fraction volume of fiber. This work conducted by Silva, L.J.S., 2012 [10], and life time prediction for the subsurface crack propogation [14]. In addition, the finite element method have been applied to simulation of natural fiber in several composite [13]. the number and mesh model used in finite element method can affect to the accuracy of the material simulation [9]. In addition, this method have been used widely in many application to material analysis of both mechanical and physical properties such as composite, metal, ceramic, and polymer materials. Mechanical properties of natural fiber not only investigation through simulation but also experiment $[1,4,7,14]$.

This research is go to design and simulate composite materials for leaf spring application to light vehicles, so that it has mechanical properties that are close to or equal to 55Si7 steel. Composite raw materials for leaf spring applications are composed of several laminas designed using hand lay-up techniques. Composite materials for leaf springs that use to design are sisal as fiber, honeycomb and aluminum alloy as core, and epoxy resin. The specimen design is done using design modeler and ACP Post software that has been integrated with ansys 19.1 software, while simulation and analysis of design results will be carried out using the finite element method as has been done by Nurhaniza, M. et al., 2010 [8] on aerospace application. Mechanical strength of composite able to enhance with fiber direction variation [3]. Based on the description above, this research is the development composite with natural fiber and its composition that thus materials can be applied to leaf spring technology that can be applied to light vehicles which generally leaf spring used in vehicles are manufacture from steel. The development carried out in this study are the materials design that applied to composite leaf spring to obtain ideal conditions so that they are compatible with steel leaf springs.

\section{Material and Methods}

This research was conducted by comparing the mechanical properties of steel 55Si7 with a composite design, where the research was carried out numerically using the finite element method [2]. Materials that used to design composite specimen in Fig. 1 namely sisal as fiber, honeycomb and aluminum as core, and epoxy resin. Physical properties of this raw material is isotropic. Composite design is done by using modeler design software for the laminas design and ACP Pre for fiber direction, laminate thickness and cores design, and combine laminas. the size of the specimen (Figure 1) that is used $99 \mathrm{~mm} \times 21 \mathrm{~mm} \times 2 \mathrm{~mm}$ which is based on the ASTM D638 standard. The specimens are tested by tensile test numerically with finite element method, and force is applied close to 200000 Newton on one side in right hand, and other side as fixed point.

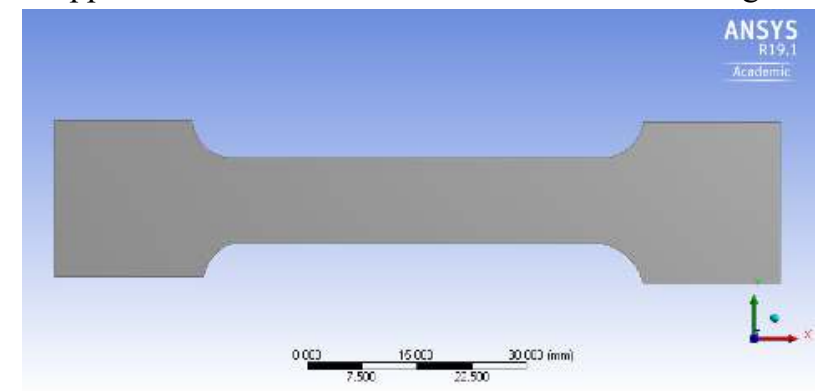

Figure 1. Specimen model of raw material. 
The next step is manucfacturing composite laminas using hand hay-up techniques with a total thickness of $2 \mathrm{~mm}$ with nine laminas. The laminas that used to modeling ply are consists of four ply of sisal-epoxy, a ply aluminum alloy and honeycomb, and four ply of sisal-epoxy. Honeycomb and aluminum alloy are used as a core for composite compositions. The direction of the fiber used for the first four layers is $09045-45$ as shown in Figure 2.

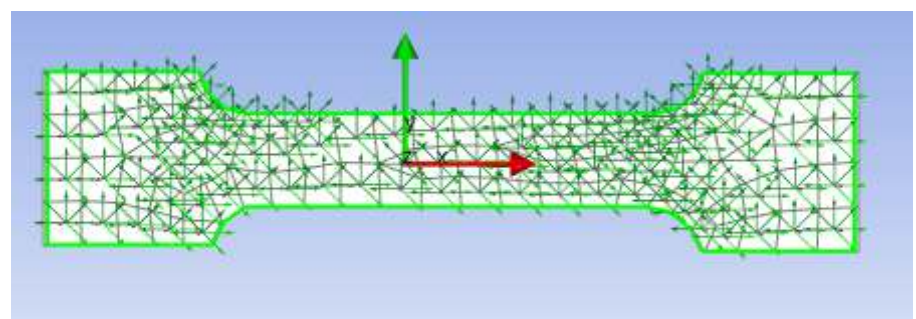

Figure 2 Fiber orientations of the fist four ply for sisal-epoxy.

and fiber orientasion of the next four ply that use in this research namely -45 45090 at Figure 3.

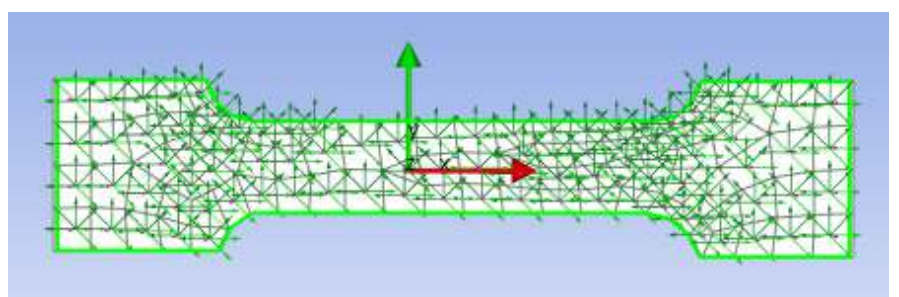

Figure 3 Fiber orientation of the second four ply for sisal-epoxy.

Combination of all ply of sisal fiber and core of both aluminum alloy and honoycomb core show in Figure 4.

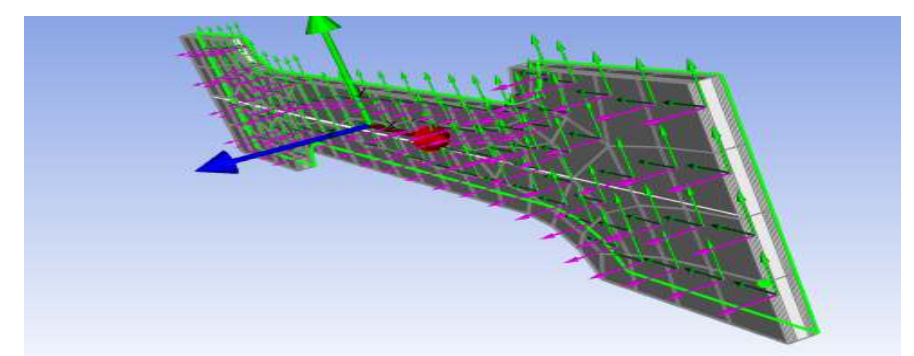

Figure 4 Raw material of composite.

Core thicknes at Figure 4 is equal to $0.8 \mathrm{~mm}$ dan thicknes eight ply of sisal epoxy laminas equal to $1.2 \mathrm{~mm}$ with thicknes of each ply is equal to $0.15 \mathrm{~mm}$. Analysis of mechanical properties both $55 \mathrm{Si} 7$ steel raw and composite raw material was carried out using finite elemen method that integrate in ansys 19.1 software. Mechanical properties that produce by $55 \mathrm{Si} 7 \mathrm{raw}$ material is to be reference to composite raw material design. 


\section{Results and Discussion}

This research is conducted to find out composition optimal of composite design that close to mechanical properties of 55Si7 raw material. Mechanical properties that is investigated such as deformation total, stress, and strain, where simulation both $55 \mathrm{Si7}$ steel and composite raw material revealed by Figure 5, Figure 6, and Figure 7.
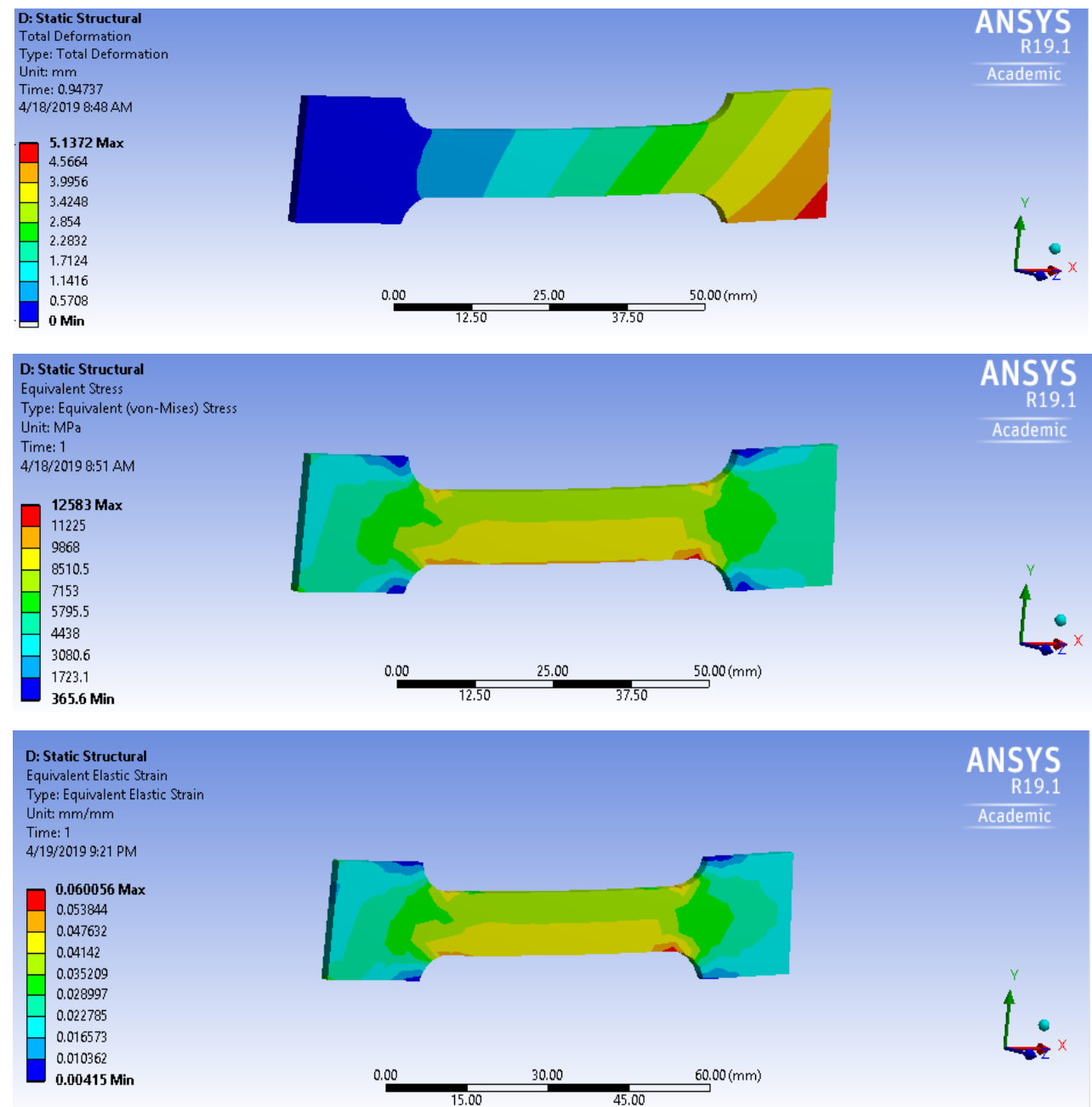

Figure 5 Total deformation, equivalen stress von mises, dan equivalen elastic strain of $55 \mathrm{Si} 7$ steel specimen. 

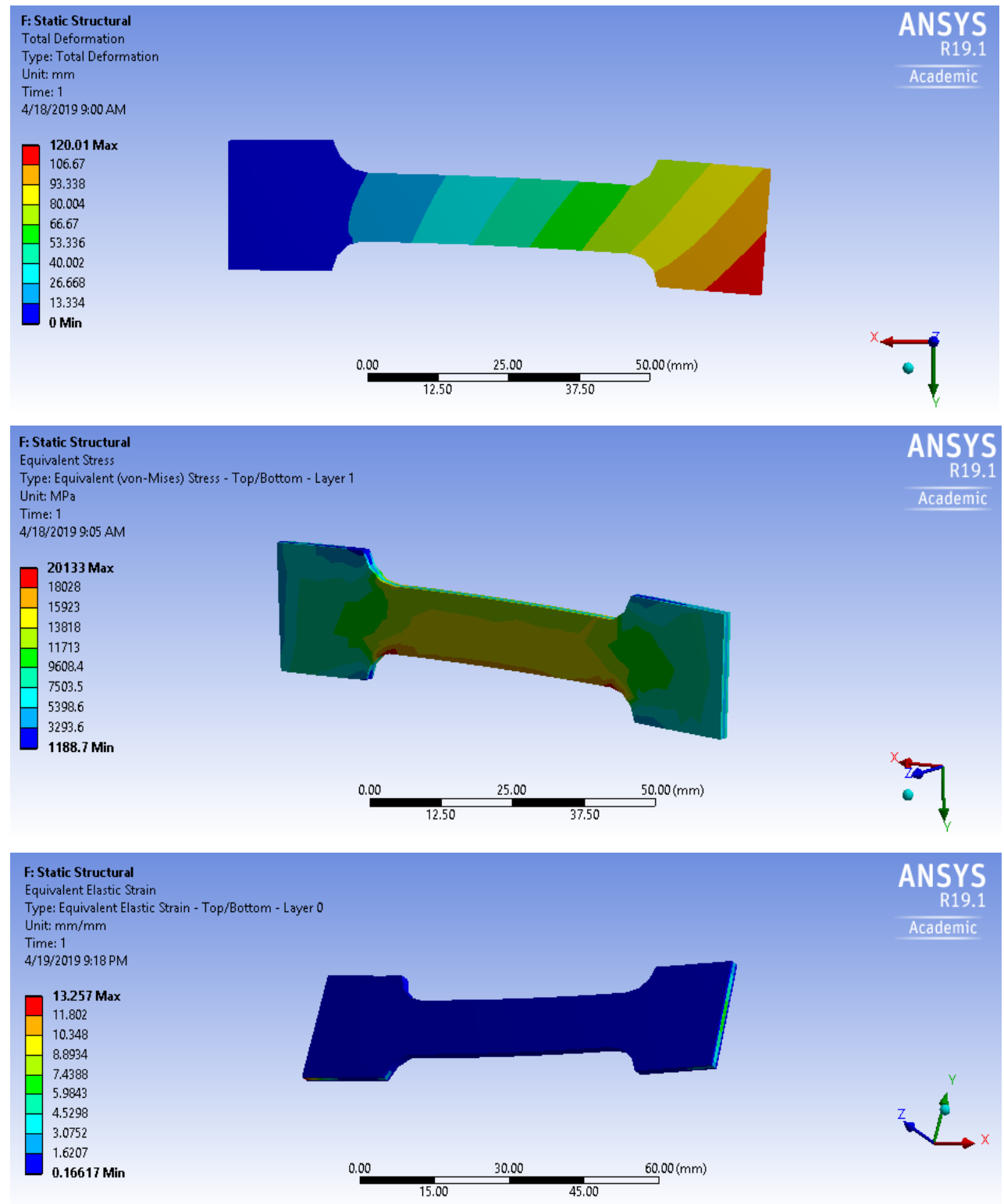

Figure 6 Total deformation composite, equivalen von mises stress, dan composite equivalen elastic strain of raw material base on honeycomb core. 

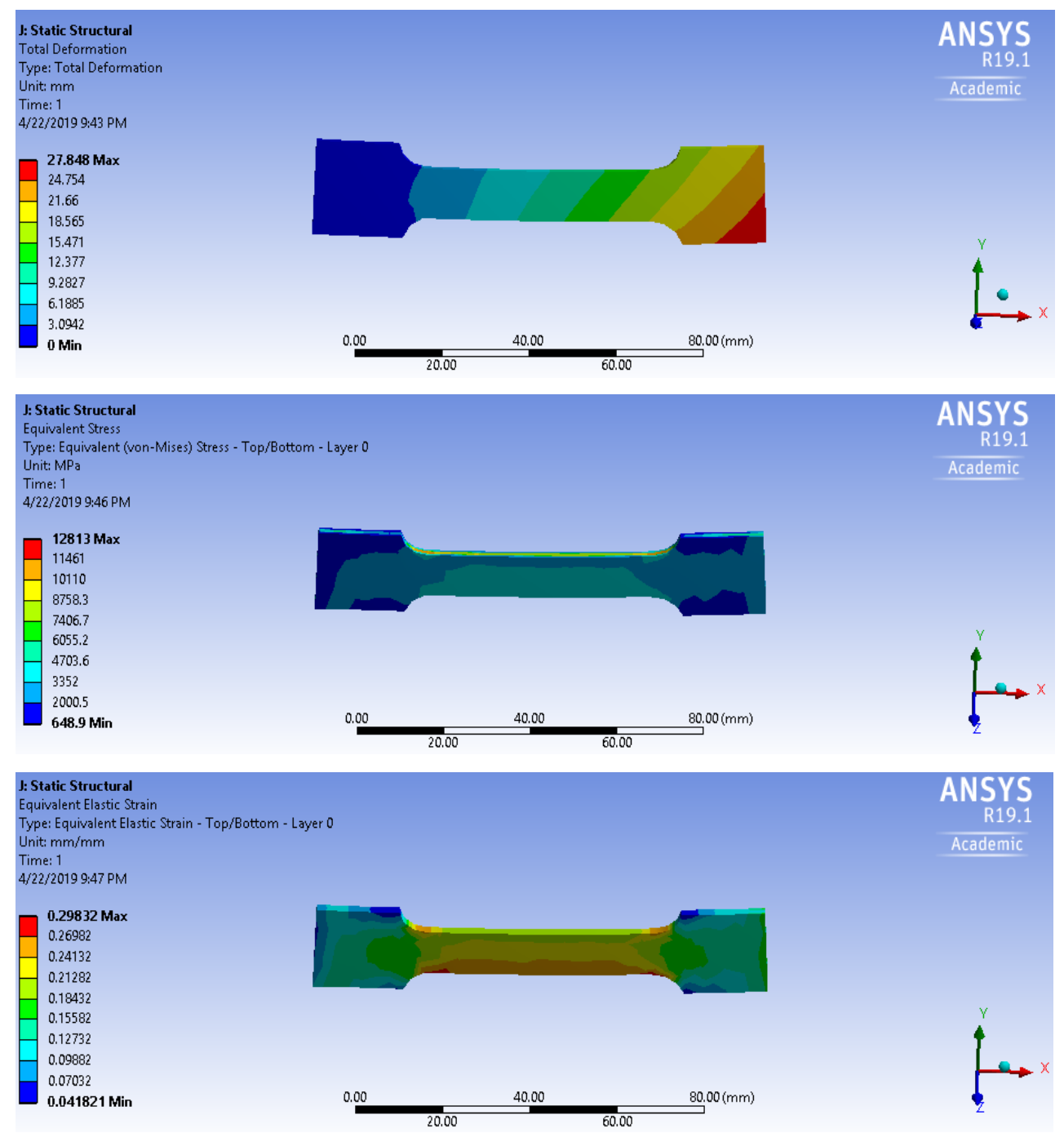

Figure 7 Total deformation composite, equivalen von mises stress, dan composite equivalen elastic strain of raw material based on aluminum core.

Figure 5, Figure 6, and Figure 7 show a comparison of the mechanical properties of the two raw materials, which are 55Si7 steel with composites base on both honeycomb core and aluminum core, where value distribution of mechanical properties are over the raw material. The results show that the total deformation averages of $55 \mathrm{Si} 7$ steel, composite base on honeycomb core, and composite base on aluminum core are shown in Table 1, where composite base on honeycomb core have the average total deformation is greater than $55 \mathrm{Si} 7$ steel and composite base on aluminum core. this result reveal that the composite based on honeycomb core designed has greater elasticity than composite base on aluminum core and 55Si7 steel. The large average strain is caused by the honeycomb material as the core as shown in Figure 6. 
Table 1. Mechanical properties of raw material.

\begin{tabular}{llllll}
\hline $\begin{array}{l}\text { Raw } \\
\text { Material }\end{array}$ & $\begin{array}{l}\text { Average total } \\
\text { deformasi } \\
(\mathrm{mm})\end{array}$ & $\begin{array}{l}\text { Min } \\
\text { equivalent } \\
\text { von mises } \\
\text { strain }(\mathrm{mm})\end{array}$ & $\begin{array}{l}\text { Max } \\
\text { equivalent } \\
\text { von mises } \\
\text { strain }(\mathrm{mm})\end{array}$ & $\begin{array}{l}\text { Min } \\
\text { equivalent } \\
\text { von mises } \\
\text { stress } \\
(\mathrm{MPa})\end{array}$ & $\begin{array}{l}\text { Max } \\
\text { equivalent } \\
\text { von mises } \\
\text { stress } \\
(\mathrm{MPa})\end{array}$ \\
$\begin{array}{l}\text { Steel 55Si7 } \\
\text { Composite }\end{array}$ & 2.92 & 0.04 & 0.06 & 365.60 & 12583 \\
$\begin{array}{l}\text { base on } \\
\text { honeycomb } \\
\text { core }\end{array}$ & 62.75 & 0.17 & 13.26 & 1403.10 & 18590 \\
$\begin{array}{l}\text { Composite } \\
\text { aluminum } \\
\text { core }\end{array}$ & 15.47 & 0.04 & 0.30 & 648.90 & 12813 \\
\hline
\end{tabular}

The equivalent elastic strain in Figure 6 shows the largest strain distribution (Table 1) in the core material, while the composite design of sisal-epoxy elastic has the strain distribution equal to $0.17 \mathrm{~mm}$. This value approach to the elastic strain of $55 \mathrm{Si} 7 \mathrm{steel} \mathrm{at} 0.04 \mathrm{~mm}$, and composite aluminum core at $0.04 \mathrm{~mm}$. In addition, the maximum stress that can be received by composite raw material is greater than $55 \mathrm{Si} 7$ steel and composite aluminum core as shown in Table 1 . This shown that the ability to receive stress is better than $55 \mathrm{Si} 7$ steel and composite aluminum core.

Composite with aluminum core have the mechanical properties close to $55 \mathrm{Si} 7$ steel as shown by Table 1 such as minimal and maximal equivalent von misses strain, and minimal and maximal von misses stress. This means that combination composite design which is equal to steel $55 \mathrm{Si} 7$ are sisal as fiber, aluminum as core of composite, and epoxy resin.

\section{Conclusion}

Design raw material 55Si7 steel and composite have been succesfully using design modeler and ACP post software, and design model has been analysis using finite element method to determine mechanical properties such as strain, strain, and total deformation. According tensile test using finite element analysis namely $55 \mathrm{Si} 7$ steel have $2.92 \mathrm{~mm}$ of deformasi total average, $12583 \mathrm{MPa}$ equivalen von mises stress, composite with honeycomb core have $62.75 \mathrm{~mm}$ of deformasi total average, and $18590 \mathrm{MPa}$ equivalen von mises stress, and composite with aluminum alloy have $62.75 \mathrm{~mm}$ total deformation average, $12813 \mathrm{MPa}$ equivalen von mises stress. According that results, composite design have mechanical properties higher than 55Si7 steel and composite with aluminum both in deformation total and strain.

Material compositions of composite raw material with natural fiber namely sisal fiber, resin epoxy, and honeycomb and aluminum alloy as core. The results of composite with honeycomb core design reveals the highest strain caused by honeycomb as core, and sisal-epoxy laminas design reveals equivalen von mises strain as 0.17 . While composite with aluminum alloy have mechanical properties close to $55 \mathrm{Si} 7$ steel such as equivalent von mises stress and strain. This can be concluded that composition design composite that close to mechanical properties of 
$55 \mathrm{Si} 7$ are sisal as fiber, aluminum alloy as core, and resin epoxy with the fiber orientation $0^{\circ}$ $90^{\circ} 45^{\circ}-45^{\circ}$ for $4 \mathrm{ply}$, and others $-45^{\circ} 40^{\circ} 0^{\circ} 90^{\circ}$. the thicknes of each ply is $0.15 \mathrm{~mm}$, and thicknes of core is $0.8 \mathrm{~mm}$.

\section{Acknowledgements}

Thanks to DRPM Kemenristekdikti and head of imaging laboratory Sumbawa University of Technology for support this research and publication.

\section{References}

[1] Bachtiar, D., Sapuan, S.M., Zainudin, E.S., Khalina , A., Dahlan K.Z.M.,: The tensile properties of single sugar palm (Arenga Pinnata) fiber. Materials Science and Engineering. pp. 1-8. doi: 10.1088/1757-899X/11/1/012012 (2010)

[2] Barbero, E.J., : Introduction to Material Composite Design third edition. CRC Pess (2017)

[3] Callister, W.D. dan Rethwisch, D.G.: Material Science and Engineering an Introduction 9e, Wiley (2014).

[4] Ibrahim, I.D., Jamiru, T., Sadiku, E.R., Kupolati, W.K., Agwuncha, S.C., and Ekundayo, G.: Mechanical Properties of Sisal Fiber-reinforced Polymer Composites: a review. Composite Interface. pp. 15-36. doi: 10.1080/09276440.2016.1087247 (2016)

[5] Justo, J., Osuna, S., and Paris, F.: Designs of Composite Materials with Improved Properties. Composites Part B. doi: 10.1016/j.compositesb.2015.02.025 (2015)

[6] Mithari, R., Patil, A., and Aitavade, E.N.: Analysis of Composite Leaf Spring by Using Analytical \& FEA. International Journal of Engineering Science and Technology. pp. 4809 - 4814 (2012)

[7] Rao, K.M. M., and Rao, K.M.: Extraction and tensile properties of natural fibers: Vakka, date and bamboo. Composite structures. pp. 288-295. doi: 10.1016/j.compstruct.2005.07.023 (2005)

[8] Nurhaniza, M., Arifin, M.K.A., Ali, A., Musthapa, F., and Noraini, A.W.: Finite Element Analysis of Composites Materials for Aerospace Aplications. Materials Science and Engineering. pp. 1-8. doi: 10.1088/1757-899X/11/1/012010 (2010)

[9] Saliba, J.E.: Use of Finite Element in Micromechanics of Natural Composites. Computers \& Structures. pp. 415-420 (1996)

[10] Silva, L.J.,S., Panzera, T.L., Christoforo, A.L., Durao, L.M.P, and Lahr, F.A.R.: Numerical and Experimental Analyses of Biocomposites Reinforcced with Natural Fiber. International Journal of Materials Engineering. pp. 43-49. doi: 10.5923/j.ijme.20120204.03 (2012)

[11]Singh, H., and Brar, G.S.: Characterization and Investigation of Mechanical Properties of Composite Materials used for Leaf Spring. materialstoday: Proceedings. pp. 5857-5863 (2018)

[12] Thippesh, L.: Fabrication of Hybrid Composite Mono-Leaf Spring with Unidirectional Glass Fibers. materialstoday: Proceedings. pp. 1980-2984 (2018)

[13] Xiong, X., Shen, S.Z., Hua, L., Liu, J.Z., Li, X., Wan, X., Miao, M.: Finite Element Models of Natural Fibers and their Composites: A review. Journal of Reinforced Plastics \& Composites. pp. 1-19. doi: http://dx.doi.org/10.1177/0731684418755552 (2018)

[14] Yin, Y., Chen Y., and Liu, L.: Lifetime Prediction for Subsurface Crack Propogation using Three-dimensional Dynamic FEA Model. Mechanical System and Signal Processing. pp. 54-70. doi: 10.1016/j.ymssp.2016.09.033 (2016) 
[15] Wambua, P., Ivens, J., Verpoest, I.: Natural fiber: can they replace glass in fiber reinforced plastics. Composite Science and Technology. pp.1259-1264. doi: https://doi.org/10.1016/S0266-3538(03)00096-4 (2003) 